\title{
THE EFFECTIVENESS OF E-LEARNING ENVIRONMENT IN DEVELOPING ACADEMIC ACHIEVEMENT AND THE ATTITUDE TO LEARN ENGLISH AMONG PRIMARY STUDENTS
}

\author{
Dr. Afaf M. ALJASER \\ ORCID: 0000-0002-5802-5978 \\ Curriculum \& English Language Methodology Department \\ Princess Nourah bint Abdulrahman University \\ Alriyad, Saudi Arabia
}

Received: 06/06/2018 Accepted: 05/09/2018

\section{ABSTRACT}

The present study aimed to identify the effectiveness of e-learning environment in developing academic achievement and the attitude towards learning English among the $5^{\text {th }}$ grade primary students. To achieve this purpose, an e-learning environment is designed and an achievement test and a scale for measuring attitude towards learning English are prepared. The quasi-experimental approach was applied to a sample of the $5^{\text {th }}$ grade students, divided into a control group taught through the traditional method and an experimental group taught through an e-learning environment. The achievement test and English learning attitude scale were applied pre- and post- teaching. The study concluded that there were statistically significant differences in favor of the experimental group in both the post-achievement test and English learning attitude scale.

Keywords: E-learning environments, academic achievement, attitude, English language learning.

\section{INTRODUCTION}

At the present time of dominant globalization, English represents the language of science and education. It is the global mean of communication, intellectual encounter and cultural understanding. Furthermore, it is the most commonly spoken language in the world and the approved language by many international bodies and used in 70\% of the world's mail (al-Sanea, 2009) (al-Garf, 2004).

Despite the efforts made by Saudi Arabia and its Ministry of Education in the development of education, in general, and English language learning, in particular, students' linguistic skills remain below the aspired objectives. Some studies revealed that the overall average of English language achievement is $(34.15 \%)$ for the middle stage and (31\%) for the secondary stage (al-Shuhri, 2014) (al-Shuhri, 2013) (al-Bunian, 2012) (al-Saghir, 2008).

Currently, teaching English in Saudi Arabia is based on traditional methods that focus on memorization instead of practicing. Accordingly, English has turned from being a tool of social communication into an order of repetition and recitation. Learning English, thus, has been devoid of its meaning and purpose. As a result, it becomes a necessity to look for the best ways for improving academic achievement of English Language among $5^{\text {th }}$ grade students.

The Eighth Conference of The Egyptian Association for Educational Technology (2001), the Tenth Conference of The Egyptian Association for Educational Technology (2005), and the $13^{\text {th }}$ Conference of Information Systems and Computer Technology (2006) recommended that educational institutions should 
take advantage of the new technology potentials and options. E-learning and the concept of the learning environment emerged in response to scientific and technological development and its impact in facilitating the learning process. Education Technology provides educational and training opportunities for students at various levels through taking advantage of modern technologies and continuously developing techniques (Al-Khedr, 2013).

In recent years, e-learning environment has emerged. It enables the display of the educational content in the form of interactive e-activities in which the learner is an active participant and the teacher is a supervisor and organizer.

The e-learning environment design is based on the Constructivism Theory, which emphasizes that the learner interprets novel information based on his/ her subjective understanding. Students are thought to use background knowledge and concepts to assist them in their acquisition of novel information. In addition, learning happens in realistic contexts and direct application that allow student involvement (Conceicao \& Daley, 2003) (Al-Wahr, 2002) (Oliver, 2000).

Moore, et al. (2011) distinguishes between e-learning environment that refers to real environment equipped with electronic tools, such as computer labs and smart classrooms; and distant learning that refers to a virtual environment exists on the internet, such as virtual labs and virtual classes.

Al- Bassiouni (2012), Abdel Hamid (2009), al-Shatti (2007), al-Khalifa (2007), Van Harmelen (2006) Atmezi (2010), Mansour (2001), and Linn (2000) refer to many e-learning environment advantages, which can make positive contributions to the educational process:

$>$ Long-life learning to improve the level of skills and knowledge and stay up to date;

$>$ Affording a constant information access and allowing social collaboration among learners;

$>$ Helping learners monitor and organize their learning process and supporting them;

$>$ Enabling learners to receive the scientific material in proportion to their abilities and previous experiences;

$>$ Enabling learners to listen to the lesson at anytime and anywhere.

Many studies have proved the importance and effectiveness of e-learning environment design in the teaching process. Aql et al. (2018) concluded the effectiveness of e-learning environment design in developing the skills of designing learning elements. Al-Sayed (2016) reached effectiveness of designing a collaborative elearning environment in developing the concepts of invisible web search engine and self-efficacy beliefs among students of the Faculty of Education. Al-Zanebat (2016) concluded the effectiveness of a proposed virtual environment in the development of cognitive tasks related to some interactive Internet applications. Furthermore, Madi (2015) proved the effectiveness of a learning environment based on social networks in developing the skills of developing e-learning environments and self-learning skills. Hassan (2015) reached the effectiveness of using an e-learning environment in improving students' academic achievement. Mooney (2014) concluded the effectiveness of using virtual learning environments to publish lectures, provide resources and enable assessment via the Internet. Al-Deferi (2014) reached the effectiveness of a program based on e-learning environment in the development of basic leadership skills. In addition, Abdul Latif (2014) concluded the effectiveness of virtual learning environments in providing students with the skills of educational designs of e-courses. Harrington \& Aloni (2013), concluded the effectiveness of e-learning environment in developing critical thinking among students. Al-Bassiouni (2012) reached the effectiveness of developing e-learning environment in improving programming writing skills. Abdel Dayem and Nassar (2012) concluded the effectiveness of using e-learning environments in achievement motivation among students of Al-Quds Open University. Hamdy (2011) reached the effectiveness of employing a personal elearning environment in the development of e-content design skills. Hou (2010) showed that the experimental group students who have studied through an e-learning environment excelled the control 
group students. Salman (2010) reached the effectiveness of using smart virtual learning environment in improving innovative thinking skills. Omale et al. (2009) concluded the effectiveness of e-learning environment in the development of cognitive and performance achievement. Arend (2009) reached the effectiveness of e-learning environment in the development of critical thinking skills.

In light of the above-mentioned studies, it is clear that there is a need to reconsider the current educational environments and to create a modern e-learning environment that copes with the requirements of the new century. The student plays a pivotal role in the educational process, Qatami (2000) pointed out that the problems facing learning English can be also attributed to the student regarding his/her desire and motivation, since the availability of these factors in the student results in better learning. The student's ability to understand the various educational topics are related not only to his/her level of mental development and abilities, but to their relevance to his/her interests, inclinations and attitudes, as well. The student's attitude, for instance, represents a basis for his/ her motivation to learn, as negative attitudes towards any course hinders the educational process (al-Husari, 2016). The purpose of studying student attitude is to interpret and predict his/ her behavior, and thus to be able to control and adjust it to suit the interests of the individual and the community. In general, attitudes can have an effective effect on the individual because they represent the cause as well as the outcome of the behavior. They are personal matters related to the individual's feelings, experiences and ways of thinking (al-Rahimi, 2016).

Due to the importance of student attitude towards learning English as an essential educational outcome that helps the student adapt to his/her surroundings, many studies have examined the effectiveness of some methods and strategies in developing the attitude of learning English among students in various educational stages. Al-Zoubi (2013), al-Saeagh (2012), and Marouf and Nasser (2010) showed the effectiveness of some methods and strategies in the development of student attitude towards learning English at various educational stages.

The researcher conducted interviews with some English language teachers and supervisors of the primary stage. The group is composed of 12 English language teachers from two primary school and four English language supervisors. They are asked about the level of the $5^{\text {th }}$ grade students' achievement in English; what are the difficulties that face students while learning English? What are the reasons for these difficulties from their perspective? What are student attitudes towards learning English? Are there any complaints from parents in relevance to learning English? After analyzing responses, results show:

$>$ Nine teachers, i.e. $75 \%$, and four supervisors, i.e. $100 \%$, referred to the low level of the fifth grade students' achievement in English Language.

$>$ Teachers and supervisors agreed that students face difficulties in learning English due to their inability to understand English Language, to interpret the short reading texts, and to write a short essay.

$>$ Three supervisors confirmed that these difficulties are attributed to the teaching method adopted by the teacher in teaching English in which the teacher plays the key role, while the learner is limited to putting down notes and answering exercises, in addition to a very little discussion.

$>$ Seven Teachers, i.e. 58.33\%, confirmed the lack of knowledge they have about modern teaching methods through which the difficulties of learning English could be overcame and academic achievement could be improved.

$>$ Teachers and supervisors agreed that there are continuous complaint from parents regarding the difficulty of the English language curriculum and the low grades that their children got in the English language examinations.

$>$ Eleven teacher reported that most students have negative attitudes towards learning English and they hate the English class. 
Therefore, the current study aims to identify the effectiveness of an e-learning environment in the development of academic achievement and attitude towards learning English among primary school students.

\section{THEORETICAL FRAMEWORK: E-LEARNING ENVIRONMENTS}

\section{The Concept of E-learning Environments}

E-learning environment is defined by Khamees (2015) as an educational technology system consisting of several educational pages uploaded on a server or hosted by an Internet service provider. The educational content is displayed through a web browser for serving educational purposes. Chou \& Liu (2005) defines it as a technical environment through which interactive e-courses are offered to students.

\section{Classification of E-learning Environments}

Al-Najar (2013), Abdel Hamid (2010) and Abdel Hamid (2009) agree on the classification of e-learning environments according to their tools, as follows:

1. Synchronous e-learning environments: Web-based learning techniques in virtual classrooms, where the teacher and the student exist at the same time, with no place limits. Direct feedback is provided instantly through tools such as:

$>$ Discussion Forums;

$>$ Chat rooms;

$>$ Video conferencing;

$>$ Audio conferencing.

2. Asynchronous e-learning environments: Classes unlimited to a specific time or place, as the teacher provides the educational content, makes it available for students to access, participate, and ask questions. feedback is provide through tools such as:

$>$ Static web pages;

$>$ E-mail;

$>$ Storage media such as CDs.

\section{Characteristics of e-learning environments}

Abu-Khatwa (2016), Albayrak and Albayrak (2016), Al-Maghawry (2015), Ahmed (2014), Romero-Frías and Arquero (2013), and Al-Khalifa (2008) agreed that the e-learning environment has the following characteristics:

1. Individualism: The learners are the ones who manages their educational content according to their individual needs.

2. Participation: The learner shares with others a certain educational content or learning experience.

3. Communication: It provides multiple ways for communication between teachers and learners, including:

$>$ One-to-one: teachers' contact with students.

$>$ One-to-many: teachers' contact with a group of students.

$>$ Many-to-many: Students' contact with each other.

4. Assessment: through tests and feedback based on student responses.

\section{Standards of Designing E-learning Environments}

Several studies have referred to the importance of the standards of designing e-learning environments. Khamees (2000) aims to define a comprehensive list of modern and accurate standards that should be considered while designing and producing multiple media. The list compromised of 144 standards of which 103 standards related to the scientific and educational aspects of design and 41 standards related to the technical aspects of designing multi-media or interactive systems. The list also covered the standards of 
educational objective, learner characteristics, content, content presentation methods, learner control of Learning, learning assessment, multi-media building standards, screen design, navigation systems, guidance, and research strategies. In addition, El-Manaei (2002) identified the standards of designing e-learning environments in four main domains. Belfer et al. (2002) identified nine main standards of designing elearning environments. Krauss \& Ally (2005) identified the eight key standards of designing e-learning environments.

\section{STATEMENT OF THE PROBLEM}

The problem of the current study can be defined in the low level of the $5^{\text {th }}$ grade student achievement and negative attitude towards English language. At the main time, the educational system of Saudi Arabia seeks to face the challenges of linguistic globalization, to improve the level of student achievement, and to construct positive attitudes towards learning English language. This situation requires transforming from traditional learning environment to e-learning environment due to its effectiveness in fixing weaknesses and improving the educational outcomes. This study attempts to answer the following main question: what is the effectiveness of e-learning environment in developing academic achievement and attitude towards learning English among $5^{\text {th }}$ grade students?

\section{Questions}

$>$ What is the effectiveness of e-learning environment in developing the $5^{\text {th }}$ grade student achievement in English language?

$>$ What are the $5^{\text {th }}$ grade student attitude towards learning English?

$>$ What is the effectiveness of e-learning environment in developing the $5^{\text {th }}$ grade student attitude towards learning English?

\section{Objectives}

The present study attempts to identify:

$>$ The effectiveness of e-learning environment in developing the $5^{\text {th }}$ grade student achievement in English language.

$>$ The $5^{\text {th }}$ grade student attitude towards learning English

$>$ The effectiveness of e-learning environment in developing the $5^{\text {th }}$ grade student attitude towards learning English.

\section{Significance}

The present study is significant because:

$>$ It tackles the e-learning environment and its effectiveness in the $5^{\text {th }}$ primary grade female students' academic achievement as it enhances their motivation and achievement in the English language course.

$>$ The e-learning environment may motivate teachers to use modern techniques as a result of improving the level and interaction of students.

$>$ The study may contribute to changing students' negative attitudes toward the English language course to positive ones.

$>$ It may contribute to acquiring students new distinguished technical skills.

$>$ It may draw the attention of the decision-makers at the Ministry of Education to the necessity of developing the teaching methods by applying modern techniques that help increase learners' academic achievement in various subjects. 


\section{Limitations}

Spatial and human limitations: A set of $5^{\text {th }}$ primary grade students at Ashbeelya School in Riyadh.

Temporal limitations: The English language curriculum (Smart Class) for the $5^{\text {th }}$ primary grade for the second semester of 201612017.

Objective limitations: Designing a web-based e-learning environment depending on ADDIE, the educational design model, and identifying its impact on developing academic achievement and attitude towards learning English language among the $5^{\text {th }}$ primary grade student.

\section{Definition of Terms}

Effectiveness: It can be defined procedurally as the building of an e-learning environment to improve the level of achievement and attitude as measured in the post-application of the achievement test and attitude scale through the statistically significant difference between the average score of the control and experimental groups among the fifth grade students in English language subject.

E-learning environment: It is procedurally defined as an environment that simulates a realistic learning environment, depends on synchronous and asynchronous communication between teachers and learners, and enables teachers to publish contents, develop activities, and communicate with students via multimedia such as (written and audio texts, pictures, and video) through an educational design model "ADDIE" for the achievement of learning purposes.

Traditional method: It can be defined procedurally as the teaching method in which the teacher displays, explains, and discusses the content of the English language subject to the $5^{\text {th }}$ grade students without actual participation or active involvement with the students.

Academic achievement: It can be defined procedurally as the progress made by students in achieving the objectives of the English language subject of the second semester for the $5^{\text {th }}$ grade students, which is measured by students' score at the achievement test.

Attitude towards learning English language: It is procedurally defined as the $5^{\text {th }}$ grade students' position towards learning English language in response to using the e-learning environment and it is measured by students' score on the scale of the attitude towards the e-learning environment.

\section{Methodology and Procedures}

Method: The quasi-experimental approach adopted to identify the effectiveness of e-learning environment in developing academic achievement and the attitude to learn English among the $5^{\text {th }}$ grade students. Two equal groups were selected: a control group taught by the traditional method and an experimental group taught by an e-learning environment via the Internet. An achievement test and an attitude scale towards learning English language are pre- and post- applied to the two groups.

\section{Variables}

$>$ Independent variable: E-learning environment via the Internet.

$>$ Dependent variable: Academic achievement and the attitude towards learning English.

\section{Population}

The population of the study covered the $5^{\text {th }}$ primary grade students (aged 10-12 years) at Ashbeelya School in Riyadh for the academic year (2016/ 2017).

\section{Sampling}

Pilot sample: It is randomly selected from (15) students of the $5^{\text {th }}$ primary grade of the first semester of the academic year (2016/2017). It is used in calculating the sychometric chracteristics of the achievement test and the attitude scale towards learning English language. 
The study sample comprised (30) students from two classes at Ashbeelya School in Riyadh of the second semester of the academic year (2016/ 2017). It was divided into two groups; the experimental group (15) and the control group (15).

\section{METHODOLOGICAL PROCEDURES}

\section{Design and Development of the E-learning Environment}

In order to design and develop the e-learning environment via the web and based on the educational design model 'ADDIE', the following stages and procedures are gone through (Khamees, 2003):

\section{First: Design of the Experimental Processing Material}

Stage 1: Analysis

Identify problems and needs: The problem has been previously identified in the low academic achievement of the English language among primary stage students.

$>$ Identify educational tasks (learning content): The author adopted the hierarchical analysis in analyzing the content of the educational unit "Smart class" and identifying educational objectives that the students mastered, which is the ultimate objective of the educational process.

$>$ Analyzing the characteristics of learners: The characteristics of (30) primary stage students were analyzed.

\section{Stage 2: Design}

Designing the procedural educational objectives of the learning content: Because the study's objective is to identify the effectiveness of the e-learning environment in academic achievement and the attitude towards the English language learning its procedural objectives are a set of behavioral objectives related to the English curriculum. Because the author relies on introducing a behavioral formulation in light of the $\mathrm{ABCD}$ model and on analyzing inputs and outputs according to their educational hierarchy, the final educational objectives were driven from the main objective of education.

$>$ Designing teaching and learning strategies: The general learning strategy, i.e. the e-learning environment, is determined through the development of an organized general plan including specific educational procedures. To achieve the educational objectives, a set of steps should be taken into account in designing the general education strategy:

- Motivating the learner to learn through

a) Attracting the attention of the learner to learn.

b) Giving the learner an overview of the learning objectives.

c) Reviewing (re-calling) the previous learning.

$>$ Designing interaction interfaces through the learning environment (Moodle)

In this step, the educational interactions in the website were identified:

$>$ Interaction with the environment and the user interface

This interaction was done through the students' dealing with the website's main interface through login and dealing with codes and links related to the content, as well as their response to the educational stimuli.

$>$ Students' interaction with the content through:

- Educational content screens.

- Click an icon, hyperlink, or icon on the screen.

- Freedom of movement between content screens.

- Answer self-assessment questions related to the content. 
- Completion of learning tasks and activities.

$>$ Students' interaction with each other: It is only achieved through the adaptive learning environment because each learner learns according to their abilities and speed.

- Building referenced tests: Based on the educational objectives and content, tests were developed for students during their study of the content.

- Identifying educational materials and activities: The educational materials, including the educational lessons and activities provided to learners after the completion of the educational content were designed, and providing additional electronic links to enrich the educational process and identifying the role of teachers as mentors and supervisors.

(4) Designing an e-learning environment (Moodle)

The author relied on several Arabic and foreign resources on the e-learning environment and was interested in the development of the educational environment in light of:

$>$ System credibility: Input data are invisible (symbolic), data entered are not lost when moving from one window to another, data modification is always made, and activation of the account is done through the learner's e-mail.

$>$ Interface design and navigation methods: The site provides navigation tools that are simple and appropriate to the characteristics of learners. The navigation buttons are available on all pages of the system and on the right side of the system pages.

$>$ Content design: The site provides content appropriate to the characteristics of learners as well as appropriate educational content to help the learner achieve the learning objectives. The text is clearly written and multimedia, including images, videos, and animations are used to design the content in order to achieve the learning objectives. The site also offers various activities and feedback on the content objectives and learners' patterns.

$>$ Ease of use: The system avoids too much technical focus on the design so as not to distract the attention of learners and provides an easy system for navigation so that all system links can work properly.

$>$ Interaction: It means interaction between the learner and the educational content by providing the dynamic content. It also allows interaction between the learner and the teacher. Such interaction is done through the control buttons and the drop-down menu; the interaction buttons should be consistent, constant, and precise.

\section{Stage 3: Production/ Development Stage}

$>$ Two-way production or development

- It is related to the development of the e-learning environment. A class was established in the name of primary stage students. The research group, i.e. 30 students, was added to the learning environment and the semester's code was e-mailed to them.

- It is the production of electronic educational content and linking it to the e-learning environment. It is represented in the production of multimedia items (images - soundtext- animation) where a collection of videos and animation, which illustrate some concepts of content learning, was utilized.

$>$ Production of learning activities Learning activities have been produced using Adobe Photoshop software in preparation for uploading them to the learning environment using a tool and setting a timeframe for implementation.

$>$ Production of electronic evaluation tools: The question bank tool used in the e-learning environment was used to put some questions related to the learning content via the eenvironment.

- Application: The present study was applied during the academic year (2016/2017). 
The study utilized two tools:

\section{The achievement test}

An English language achievement test was prepared after analysing the content of the English language subject to the cognitive learning aspects included in the topics of the subject. The final form of the test formulated comprising (10) multiple choice questions.

$>$ Validity: In order to verify the validity of the test, it was submitted to a set of faculty members $(\mathrm{N}=5)$ specialized in Curriculum and Instruction and also to a set of faculty members $(\mathrm{N}=3)$ specialized in Evaluation and Measurment. In the light of their opinions, modifications were made and the final form of the test approved after omitting one question and rephrasing the beginning of two questions.

$>$ Internal validity :The internal validity of the acheivement test items is estimated by caluculating the correlation coefficient between the score of each item and the total score of test. Coefficients were in the closed interval (0.34-0.92), and thus they are statistically significant at 0.01 indicating the internal validity of the acheivement test items.

$>$ Reliability: Cronbach's alpha was applied to estimate the reliability of the test. It was (0.92) at the significance level of (0.01), indicating the high reliability of the test.

\section{Time of the test}

Students were given enough time to answer the acheivement test questions. The time taken by each student to answer the questions was recorded and the average time of student response was calculated. It showed that 15 minutes is the time required for answering the acheivement test questions.

\section{Second: Scale of the Attitude towards Learning English}

The author applied a 33-item questionnaire to measure the $5^{\text {th }}$ primary grade students' attitude towards learning English. Items No. (3- 14- 18- 22- 23-26- 27-28-32-33) were placed in the opposite direction, where (strongly agree $=1$, agree $=2$, and disagree $=3$ ), and the rest of items were the positive ones.

$>$ Validity: In order to verify the validity of the attitude scale, it was submitted to a set of faculty members $(\mathrm{N}=7)$ specialized in Curriculum and Instruction and also to a set of faculty members $(\mathrm{N}=5)$ specialized in Evaluation and Measurment. In the light of their opinions, modifications were made and the final form of the test approved after omitting some items for their inapproporiateness or repeatedness.

> Internal validity: To verify the internal validity of the scale, Pearson Correlation Coefficient between the score of each item and the total score of the scale was calculated. The correlation coefficients were (0.22: 0:92); all of them were statistically significant at the level of (0.01) and (0.05), illustrating the internal validity of the test.

$>$ Reliability: In order to estimate the reliability of the scale, Cronbach's Alpha applied to the sample and was $(0.829)$ which indicates that the scale is highly reliable.

\section{Testing the study variables}

$>$ pre-achievement test: The achievement test (the study tool) was applied to the experimental and the control groups before teaching the English language subject. Mann-Whitney Test was used to identify the significance of the differences between the average responses of the experimental and the control groups.

> Attitude scale towards learning English: The attitude scale (the study tool) was applied to the experimental and the control groups before teaching the English language subject. Mann-Whitney Test was used to identify the significance of the differences between the average responses of the experimental and the control groups. 
Table 1. Mann-Whitney Test to identify the significance of the differences between the average responses of the experimental and control groups to the pre-achievement test and the scale of the attitude towards

learning English

\begin{tabular}{ccccccc}
\hline & Study groups & No. & Mean of ranks & $\begin{array}{c}\text { Total of } \\
\text { ranks }\end{array}$ & $\begin{array}{c}\text { Critical } \\
\text { value (z) }\end{array}$ & $\begin{array}{c}\text { Significance } \\
\text { level }\end{array}$ \\
\hline Achievement test & Control & 15 & 13.77 & 206.50 & -1.079 & 0.285 \\
$\begin{array}{c}\text { Exale of the attitude } \\
\text { towards learning } \\
\text { English }\end{array}$ & Control & 15 & 17.23 & 258.50 & & Insignificant \\
\hline
\end{tabular}

Table (1) shows that there are no statistically significant differences between the mean scores of the experimental group and the control one in pre-achievement test and the attitude scale towards learning English, illustrating the equivalence of the groups in the pre-test of the attitude towards learning English.

\section{RESULTS AND DISCUSSION}

\section{Answering the First Question: What is the Effectiveness of E-Learning Environment in Developing the $5^{\text {th }}$ Grade Student Achievement in English Language?}

To identify whether there are statistically significant differences between the mean scores of the students of the experimental group (taught through e-leaning environment) and those of the control group (taught by the traditional method) in the post-achievement test, Eta Square (T Value) was applied. It indicates a contrast ratio in the dependent variable due to the independent one. The effect size illustrates the ratio between the mean scores of both groups in normative units, as shown in table (2).

Table 2. Mean, number of students, freedom degree, $(T)$ value, and value and significance of Eta Square

${ }^{2} \eta$ in the post-achievement test

\begin{tabular}{|c|c|c|c|c|c|c|c|}
\hline & Study groups & No. & Average & $\begin{array}{c}\text { Freedom } \\
\text { degree }\end{array}$ & (T) value & $(\eta 2)$ & Effect size \\
\hline $\begin{array}{l}\text { Achievement } \\
\text { test }\end{array}$ & $\begin{array}{c}\text { Control } \\
\text { Experimental }\end{array}$ & $\begin{array}{l}15 \\
15\end{array}$ & $\begin{array}{l}23.15 \\
30.97\end{array}$ & 28 & 4.191 & 0.39 & $\begin{array}{c}\text { Significant } \\
\text { effect }\end{array}$ \\
\hline
\end{tabular}

Table (2) shows that there a statistically significant difference between the average scores of students in the control and the experimental groups in the post-application of the achievement test at the level of 0.01 , in favor of the students of the experimental group. It means that the level of student achievement in the experimental taught through the e-learning environment is higher than the level of student achievement in the control group taught through the traditional method. The effect size of the independent variable (elearning environment) on the dependent variable (academic achievement) is significant, indicating the effectiveness of e-learning environment in the development of academic achievement among fifth grade primary students. Thus, the first study question is answered.

The present study agrees with Al-Sayed (2016), Fadel (2016), Sayed (2016), Ibraheem and Ismail (2014), Konlechner (2014), Al-Muteiri (2008) and Chou and Liu (2005) in terms of the effectiveness of e-learning environments in developing the cognitive achievement of students. It is also consistent with Wu (2018) emphasizing that e-learning environment helps understand complicated subjects using pictures and charts.

These results can be interpreted that the use of the e-learning environment, the various means of communication it offers, the availability of services and powers such as dialogue and discussion among students, and the provision of content in the form of video clips and formative tests following each lecture. The overall and learning objectives of the learning content were set. As a result, the level of academic 
achievement and the achievement of the overall objective of study, i.e. increasing academic achievement, were improved. The educational content was hierarchically analyzed, which helped obtain information in a correct and easy way. The diversity and use of learning and presentation items such as texts, images, animation, and video clips attract learners' attention to the content of the e-learning environment and give greater opportunities for learning by using many senses simultaneously. In addition to the constant availability of the content via the e-learning environment, so that learners can follow it in a timely manner and support their concept of self-learning. The diversity of reinforcement methods in terms of immediate reinforcement after carrying out the assessment of each topic and the author's reinforcement to the students of the study group during the continuous follow-up through the means of communication. This reinforcement is associated with their achievement in the test and their inquiries about the obstacles that noticeably helped improve their achievement. Therefore, they pursued the performance of positive reinforcement and avoided the one that caused negative reinforcement. Furthermore, providing the learning content via the educational environment (Moodle) in a manner appropriate to the learners' abilities and potentials, where self-learning was the adopted style and their cognitive achievement increased. The elearning environment helped organize students' ideas and connect concepts and skills. The ease of using the e-environment, teacher-learner interaction, learner-interface interaction, and learner-peer interaction had a positive effect on increasing the interaction of students with the learning content. The use of Moodle does not require complex technical skills; it is adequate to teach students how to record and navigate within the electronic environment and to perform activities and upload them to the e-learning environment. This helped maintain learning motivation and eliminate the fear and anxiety of using e-learning environments.

\section{Answering the Second Question: What are the $5^{\text {th }}$ Grade Student Attitude towards Learning English?}

In order to identify the attitude of $5^{\text {th }}$ primary grade students towards using the e-learning environment in teaching a unit of the English language curriculum, frequencies, percentages, arithmetic means, standard deviations, and ranks of the responses of the participants were estimated. Results are as follows:

Table 3. Responses of the participants to using the e-learning environment in teaching a unit of the English language curriculum in a descending order according to agreement

\begin{tabular}{|c|c|c|c|c|c|c|c|c|}
\hline \multirow[b]{2}{*}{ No. } & \multirow[b]{2}{*}{ Item } & \multirow{2}{*}{$\begin{array}{l}\text { Frequency } \\
\text { Percentage }\end{array}$} & \multicolumn{3}{|c|}{ Agreement } & \multirow[b]{2}{*}{$\begin{array}{l}\text { Arithmetic } \\
\text { mean }\end{array}$} & \multirow[b]{2}{*}{$\begin{array}{l}\text { Standard } \\
\text { deviation }\end{array}$} & \multirow[b]{2}{*}{ Rank } \\
\hline & & & $\begin{array}{l}\text { Strongly } \\
\text { agree }\end{array}$ & Agree & Disagree & & & \\
\hline \multirow[b]{2}{*}{33} & \multirow{2}{*}{$\begin{array}{l}\text { The English language subject is } \\
\text { more important than other subjects. }\end{array}$} & Freq. & 11 & 3 & 1 & \multirow[b]{2}{*}{2.67} & \multirow[b]{2}{*}{0.617} & \multirow[b]{2}{*}{1} \\
\hline & & $\%$ & 73.3 & 20.0 & 6.7 & & & \\
\hline \multirow{2}{*}{27} & \multirow{2}{*}{$\begin{array}{l}\text { I wish the English language subject } \\
\text { be given top priority. }\end{array}$} & Freq. & 11 & 2 & 2 & \multirow{2}{*}{2.60} & \multirow{2}{*}{0.737} & \multirow{2}{*}{2} \\
\hline & & $\%$ & 73.3 & 13.3 & 13.3 & & & \\
\hline \multirow{2}{*}{23} & \multirow{2}{*}{$\begin{array}{l}\text { I come early in the English language } \\
\text { classes. }\end{array}$} & Freq. & 12 & & 3 & \multirow{2}{*}{2.60} & \multirow{2}{*}{0.828} & \multirow[b]{2}{*}{3} \\
\hline & & $\%$ & 80.0 & & 20.0 & & & \\
\hline \multirow{2}{*}{26} & \multirow{2}{*}{$\begin{array}{l}\text { I think there is a dire need for the } \\
\text { English language. }\end{array}$} & Freq. & 11 & 1 & 3 & \multirow{2}{*}{2.53} & \multirow{2}{*}{0.834} & \multirow{2}{*}{4} \\
\hline & & $\%$ & 73.3 & 6.7 & 20.0 & & & \\
\hline \multirow{2}{*}{19} & \multirow{2}{*}{$\begin{array}{l}\text { I feel that learning English makes } \\
\text { travel easier. }\end{array}$} & Freq. & 9 & 3 & 3 & \multirow[b]{2}{*}{2.40} & \multirow[b]{2}{*}{0.828} & \multirow[b]{2}{*}{5} \\
\hline & & $\%$ & 60.0 & 20.0 & 20.0 & & & \\
\hline \multirow{2}{*}{28} & \multirow{2}{*}{$\begin{array}{l}\text { I get annoyed by any extracurricular } \\
\text { activities not related to the English } \\
\text { language. }\end{array}$} & Freq. & 9 & 3 & 3 & \multirow{2}{*}{2.40} & \multirow{2}{*}{0.828} & \multirow{2}{*}{5} \\
\hline & & $\%$ & 60.0 & 20.0 & 20.0 & & & \\
\hline
\end{tabular}




\begin{tabular}{|c|c|c|c|c|c|c|c|c|}
\hline \multirow[b]{2}{*}{ No. } & \multirow[b]{2}{*}{ Item } & \multirow{2}{*}{$\begin{array}{l}\text { Frequency } \\
\text { Percentage }\end{array}$} & \multicolumn{3}{|c|}{ Agreement } & \multirow[b]{2}{*}{$\begin{array}{c}\text { Arithmetic } \\
\text { mean }\end{array}$} & \multirow[b]{2}{*}{$\begin{array}{l}\text { Standard } \\
\text { deviation }\end{array}$} & \multirow[b]{2}{*}{ Rank } \\
\hline & & & $\begin{array}{l}\text { Strongly } \\
\text { agree }\end{array}$ & Agree & Disagree & & & \\
\hline \multirow[b]{2}{*}{14} & \multirow[b]{2}{*}{$\begin{array}{l}\text { I'm keen on following the teachers' } \\
\text { explanation of the English lessons. }\end{array}$} & & 10 & 1 & 4 & \multirow[b]{2}{*}{2.40} & \multirow[b]{2}{*}{0.910} & \multirow[b]{2}{*}{6} \\
\hline & & $\begin{array}{c}\text { Freq. } \\
\%\end{array}$ & 66.7 & 6.7 & 26.7 & & & \\
\hline \multirow[b]{2}{*}{4} & \multirow{2}{*}{$\begin{array}{l}\text { Learning English contributes to the } \\
\text { advancement of the society }\end{array}$} & Freq. & 8 & 4 & 3 & \multirow[b]{2}{*}{2.33} & \multirow[b]{2}{*}{0.816} & \multirow[b]{2}{*}{7} \\
\hline & & $\%$ & 53.3 & 26.7 & 20.0 & & & \\
\hline \multirow[b]{2}{*}{22} & \multirow{2}{*}{$\begin{array}{l}\text { I think that learning English is not } \\
\text { at the expense of the Arabic } \\
\text { language. }\end{array}$} & Freq. & 9 & 2 & 4 & \multirow[b]{2}{*}{2.33} & \multirow[b]{2}{*}{0.900} & \multirow[b]{2}{*}{8} \\
\hline & & $\%$ & 60.0 & 13.3 & 26.7 & & & \\
\hline \multirow[b]{2}{*}{6} & \multirow{2}{*}{$\begin{array}{l}\text { Mastering English facilitates using } \\
\text { technology in social } \\
\text { communication. }\end{array}$} & Freq. & 9 & 2 & 4 & \multirow[b]{2}{*}{2.33} & \multirow[b]{2}{*}{0.900} & \\
\hline & & $\%$ & 60.0 & 13.3 & 26.7 & & & 8 \\
\hline & Learning English helps understand & Freq. & 8 & 3 & 4 & & & \\
\hline 20 & the traditions of other countries. & $\%$ & 53.3 & 20.0 & 26.7 & 2.27 & 0.884 & 9 \\
\hline & I feel that English language classes & Freq. & 8 & 3 & 4 & & & \\
\hline 18 & pass quickly. & $\%$ & 53.3 & 20.0 & 26.7 & 2.27 & 0.884 & 9 \\
\hline & I pay attention to understand the & Freq. & 6 & 6 & 3 & & & \\
\hline 13 & $\begin{array}{l}\text { teacher's explanation of the English } \\
\text { lessons. }\end{array}$ & $\%$ & 40.0 & 40.0 & 20.0 & 2.20 & 0.775 & 10 \\
\hline & I try to do assignments required by & Freq. & 7 & 4 & 4 & & & \\
\hline 15 & teachers in a timely manner. & $\%$ & 46.7 & 26.7 & 26.7 & 2.20 & 0.862 & 11 \\
\hline & The English language subjects I & Freq. & 7 & 4 & 4 & & & \\
\hline 9 & learn are useful in my daily life. & $\%$ & 46.7 & 26.7 & 26.7 & 2.20 & 0.862 & 11 \\
\hline & & Freq. & 7 & 4 & 4 & & & \\
\hline 3 & I like reading books in English. & $\%$ & 46.7 & 26.7 & 26.7 & 2.20 & 0.862 & 11 \\
\hline & I avoid being distracted during the & Freq. & 8 & 2 & 5 & & & \\
\hline 16 & teachers' explanation. & $\%$ & 53.3 & 13.3 & 33.3 & 2.20 & 0.941 & 12 \\
\hline & I feel sad for the absence of the & Freq. & 7 & 3 & 5 & & & \\
\hline 32 & English language teacher. & $\%$ & 46.7 & 20.0 & 33.3 & 2.13 & 0.915 & 13 \\
\hline & English lessons make me curious to & Freq. & 7 & 3 & 5 & & & \\
\hline 8 & access new knowledge & $\%$ & 46.7 & 20.0 & 33.3 & 2.13 & 0.915 & 13 \\
\hline & & Freq. & 6 & 4 & 5 & & & \\
\hline 1 & Tm keen on learning English. & $\%$ & 40.0 & 26.7 & 33.3 & 2.07 & 0.884 & 14 \\
\hline & The English language helps me & Freq. & 7 & 2 & 6 & & & \\
\hline 2 & understand life better. & $\%$ & 46.7 & 13.3 & 40.0 & 2.07 & 0.961 & 15 \\
\hline & I seek deeper learning of the & Freq. & 8 & & 7 & & & \\
\hline 11 & English language. & $\%$ & 53.3 & & 46.7 & 2.07 & 1.033 & 16 \\
\hline & I seek developing my skills in & Freq. & 6 & 3 & 6 & & & \\
\hline 12 & English speaking and writing. & $\%$ & 40.0 & 20.0 & 40.0 & 2.00 & 0.926 & 17 \\
\hline & The more I master English, the & Freq. & 6 & 3 & 6 & & & \\
\hline 10 & higher my life skills become. & $\%$ & 40.0 & 20.0 & 40.0 & 2.00 & 0.926 & 17 \\
\hline
\end{tabular}




\begin{tabular}{|c|c|c|c|c|c|c|c|c|}
\hline \multirow[b]{2}{*}{ No. } & \multirow[b]{2}{*}{ Item } & \multirow{2}{*}{$\begin{array}{l}\text { Frequency } \\
\text { Percentage }\end{array}$} & \multicolumn{3}{|c|}{ Agreement } & \multirow[b]{2}{*}{$\begin{array}{l}\text { Arithmetic } \\
\text { mean }\end{array}$} & \multirow[b]{2}{*}{$\begin{array}{l}\text { Standard } \\
\text { deviation }\end{array}$} & \multirow[b]{2}{*}{ Rank } \\
\hline & & & $\begin{array}{l}\text { Strongly } \\
\text { agree }\end{array}$ & Agree & Disagree & & & \\
\hline \multirow{2}{*}{31} & \multirow{2}{*}{$\begin{array}{l}\text { I enjoy solving the activities of the } \\
\text { English language. }\end{array}$} & Freq. & 6 & 2 & 7 & \multirow{2}{*}{1.93} & \multirow{2}{*}{0.961} & \multirow{2}{*}{18} \\
\hline & & $\%$ & 40.0 & 13.3 & 46.7 & & & \\
\hline \multirow{2}{*}{21} & \multirow{2}{*}{$\begin{array}{l}\text { Learning English allows broader } \\
\text { communication with the world. }\end{array}$} & Freq. & 6 & 2 & 7 & \multirow{2}{*}{1.93} & \multirow{2}{*}{0.961} & \multirow{2}{*}{18} \\
\hline & & $\%$ & 40.0 & 13.3 & 46.7 & & & \\
\hline \multirow{2}{*}{29} & \multirow{2}{*}{$\begin{array}{l}\text { I feel emotionally comfort when I } \\
\text { learn English. }\end{array}$} & Freq. & 6 & 1 & 8 & \multirow{2}{*}{1.87} & \multirow{2}{*}{0.990} & \multirow{2}{*}{19} \\
\hline & & $\%$ & 40.0 & 6.7 & 53.3 & & & \\
\hline \multirow[b]{2}{*}{7} & \multirow{2}{*}{$\begin{array}{l}\text { Learning English is interesting and } \\
\text { exciting. }\end{array}$} & Freq. & 5 & 3 & 7 & \multirow[b]{2}{*}{1.87} & \multirow[b]{2}{*}{0.915} & \multirow[b]{2}{*}{20} \\
\hline & & $\%$ & 33.3 & 20.0 & 46.7 & & & \\
\hline \multirow[b]{2}{*}{24} & \multirow{2}{*}{$\begin{array}{l}\text { I feel comfortable when I study } \\
\text { English. }\end{array}$} & Freq. & 4 & 4 & 7 & \multirow[b]{2}{*}{1.80} & \multirow[b]{2}{*}{0.862} & \multirow[b]{2}{*}{21} \\
\hline & & $\%$ & 26.7 & 26.7 & 46.7 & & & \\
\hline \multirow{2}{*}{5} & \multirow{2}{*}{$\begin{array}{l}\text { I'm keen on spending longer time } \\
\text { learning English. }\end{array}$} & Freq. & 4 & 4 & 7 & & & \\
\hline & & $\%$ & 26.7 & 26.7 & 46.7 & 1.80 & 0.862 & 21 \\
\hline & I avoid side talks during the & Freq. & 4 & 4 & 7 & & & \\
\hline 17 & English class. & $\%$ & 26.7 & 26.7 & 46.7 & 1.80 & 0.862 & 21 \\
\hline & The English language fulfills my & Freq. & 3 & 4 & 8 & & & \\
\hline 25 & desires and needs. & $\%$ & 20.0 & 26.7 & 53.3 & 1.67 & 0.816 & 22 \\
\hline & I wish to become an English & Freq. & 4 & 2 & 9 & & & \\
\hline 30 & language teacher. & $\%$ & 26.7 & 13.3 & 60.0 & 1.67 & 0.900 & 23 \\
\hline Tota & mean & & & & & 2.15 & 0.504 & \\
\hline
\end{tabular}

Table (3) shows that the participants agree on using the e-learning environment in teaching the English curriculum with a mean of (2.15 out of 3.00), in the second rank of the triple scale (from 1.67 to 2.33) indicating "agree".

Results reveal that there is a difference in the agreements of the participants to using the e-learning environment in teaching English, with means ranging from (1.67) to (2.67) indicating (agree/strongly agree). These results are consistent with Yang (2016), noting that the e-learning environment has increased student motivation for learning. In addition, Abu Shaqer (2014) illustrated that the students generally have positive attitudes towards learning English and Al-ghamdy (2012) noted that students have positive attitudes towards learning English language because it facilitates traveling abroad and helps them identify the customs, traditions, and cultures of the communities speaking in English.

This result is inconsistent with Aouachria (2015) that indicated that students' attitudes towards learning English were negative. The previous results show that participants have positive attitudes towards learning English, which may be attributed to the student desire to master English language because of its importance in their lives. The results show that the participants strongly agree that the English language is more important than other subjects, they wish English be given top priority, they are in a bad need for English, and learning English facilitates their travel abroad and helps them identify the traditions of other countries. Furthermore, the use of modern, interesting, enjoyable and attractive teaching methods such as the elearning environment promotes the attitudes of students towards English. The results show that the participants strongly agree to attend early in the English language classes, the desire to follow the teacher's explanation interestingly in the English language lesson, and the feeling that the time of studying English 
language passes quickly, as well as paying attention to what the teacher explains. The e-learning environment utilizes images, shapes, and colors easily and flexibly in building the learning environment in an innovative computer environment as the computer is an attraction for students and is supported by many items of excitement that motivate students' positive attitudes toward English.

\section{Answering the Third Question: What is the Effectiveness of E-Learning Environment in Developing the $5^{\text {th }}$ Grade Student Attitude towards Learning English?}

In order to identify whether there are statistically significant differences between the post-mean scores of the students of the experimental and the control groups on the attitude scale towards learning English, the author applied Mann-Whitney Test and the results are as follows:

Table 4: Mann-Whitney Test to identify the statistical differences between the post-mean scores of the students of the experimental and the control groups on the scale of the attitude towards learning English

\begin{tabular}{lcccccc}
\hline & Study groups & No. & $\begin{array}{c}\text { Average of } \\
\text { ranks }\end{array}$ & $\begin{array}{c}\text { Total of } \\
\text { ranks }\end{array}$ & $\begin{array}{c}\text { Critical } \\
\text { value }(\mathrm{z})\end{array}$ & $\begin{array}{c}\text { Significance } \\
\text { level }\end{array}$ \\
\hline $\begin{array}{l}\text { Scale of the } \\
\text { attitude towards }\end{array}$ & Control & 15 & 11.27 & 169.00 & & $* 2.236$ \\
\begin{tabular}{l} 
learning English \\
\hline
\end{tabular} & Experimental & 15 & 19.73 & 296.00 & -2.008 \\
Significant
\end{tabular}

Table (4) shows that there are differences between the mean scores of the experimental and the control groups in the post-test of the scale of the attitude towards learning English at the level of (0.05). This indicates that the scale of the attitude of the experimental group is better than that of the control one after the application of the e-learning environment. As a result, there are statistically significant differences at the level of $\leq(0.05)$ between the mean of ranks of the experimental and the control groups in the post-test of the scale of the attitude towards learning English, in favor of the experimental group.

These results are consistent with Yang (2016) and Al-ghamdy (2012) emphasizing the effectiveness of elearning environment in improving student attitude. The author attributed this result to the importance of using the e-learning environment and its effective role in teaching English language, given that it relies on the inclusion of images and shapes and the use of colors with ease and flexibility. It is also connected to many applications such as presentations and documents, which give flexibility in providing information and increasing its survival. Accordingly, English language is simplified and facilitated and the motivation of students to learn is enhanced in order to have positive attitudes towards English language. The digital learning environment with multimedia (i.e. video, sounds, and animation) enhanced students' use of the different senses and increased motivation for learning and attention. Additionally, the use of the keyboard and mouse enabled students to navigate through the digital learning environment easily.

\section{RECOMMENDATIONS}

In light of the previous results, the author recommends employing e-learning environments in practice and affording the required infrastructure for applying e-learning, including preparing qualified cadres as well as the provision of Internet lines and computers. In addition, students should be trained to use e-learning environment and rewards should be given to students who participate. Development of education based on e-learning environment should be encouraged in Education Technology department at the colleges of Education. Setting up plans for disseminating the culture of e-learning among teachers, in general, and English language teachers, in particular. 


\section{BIODATA and CONTACT ADDRESSES of AUTHOR}

Dr. Afaf Mohammed AL - JASSER, Associate Professor at the University of Princess Noura bint Abdulrahman Faculty of Education, Department of Curriculum and Teaching Methods. Books publishedTraining program to develop the competencies of the management of the classroom. Educational classroom time management. A number of courses have been taught, including: organization and management of the classroom, introduction to the curriculum. Curriculum bases, tests and educational evaluation, primary school, primary school curriculum. I have worked in various administrative positions at the university.

Dr. Afaf Mohammed AL - JASSER

Department, Faculty

Address: Princess Nourah bint Abdulrahman University, 11671, Alriyad, Saudi Arabia

Phone: 00966503298700.

E-mail: dr.afaf1@hotmail.com.

\section{REFERENCES}

Abu-Khatwa, A. (2016). Massive open online courses (MOOCs) and the globalization of education. Magazine of E-Learning, 14.

Abu Shaqer, M. (2014). The impact of using blended learning in teaching writing in English on developing the attitudes of $10^{\text {th }}$ grade students in Gaza towards its use. Journal of Reading and Learning, 157, $145-172$.

Ahmed, R. (2014). The effectiveness of virtual and personal learning environments in acquiring student teachers some skills in computer security and attitude towards it ( $\mathrm{PhD}$ thesis). The Institute of Educational Studies, Cairo University, Cairo.

Atmezi, G. (2010). A flexible e-learning management system to support education in traditional open universities. Available at: https://sites.google.com/site/jamilitmazi/arb

Al- Bassiouni, M. (2012). Develop an e-learning environment in the light of constructive learning theories to develop programming skills among student teachers of Computer. Journal of the Faculty of Education, Mansoura, 2(78), 293-371.

Al-Bunian, A. (2012). The level of Saudi students in English at the intermediate and secondary stages in governmental and private schools: a comparative study. Journal of King Faisal University (Humanities and administrative science), 4 (1), 179-2004.

Al-Garf, R. S. (2004). Youth attitude Towards the Use of Arabic and English languages in Education. Available at: http://www.diwanalarab.com.spip.php118k? Article748

Hassan, I. S. (2015). The use of virtual classes in distance learning program from Faculty members' perspective, King Abdulaziz University, Jeddah. (Master Thesis). Umm Al-Qura University, Saudi Arabia.

Al-Husari, A. (2016). The Attitudes of First Year Secondary Students towards the Contents of the Royal Geography Unit and its Relationship to Sex, specialization, and teaching strategy. University of Damascus, Syria, 2 (2). Available at: http:www.damascusuniversity.edu.sy...mag/53000.pd

Albayrak, M., \& Albayrak, G. (2016). E-Learning Environments for New Generation. Journal of Suleyman Demirel University Institute of Social Sciences, 1030-1037.

Al-ghamdy, M. (2012). Using SMS as a supportive method of teaching and its impact on achievement and attitudes of the Preparatory Year students at Al-Baha University towards English language learning (MA. thesis). Al- Baha University, KSA. 
Al-Khalifa, H. (2007). Modern trends and developments in the e-learning service: A comparative study among four models of distance learning. King Saud University, Riyadh, Saudi Arabia. A working paper presented to the seminar: the Future School, College of Education.

Al-Khalifa, H. (2008). Comparison between blogs and Jusur learning management system. A paper presented at the First Conference for E-learning and Distance Learning, Riyadh.

Al-Khedr, E. (2013). The Learning environment. Kingdom of Saudi Arabia: Imam Muhammad ibn Saud Islamic University.

Al-Maghawry, T. (2015). Virtual university. E-learning Magazine, 9, 1-41.

Al-Muteiri, M. (2013). Personal e-learning environments and their effect on the education process (PhD thesis). Faculty of Specific Education, Ain Shams University.

Al-Sayed, A. (2016). Designing a virtual environment based on social networks for the development of academic achievement and attitude towards teamwork among hearing impaired students (MA thesis). Faculty of Education. Mansoura University.

Aouachria, E. (2015). Attitudes of middle school students towards learning English as a second foreign language in Algeria. Journal of Educational and Psychological Sciences, 16(1), 475-497.

Al-Zanebat, A. (2016). A proposed e-environment for the development of cognitive tasks associated with some web-based Interactive applications among faculty members at Mu'tah University. Journal of Reading and Knowledge, 173, 217-238.

Al-Rahimi, A. (2016). Difficulties Facing the Students of the Preparatory Year at the Saudi Electronic University in learning English and their attitudes towards it. Journal of Reading and Knowledge, 176.57-94.

Al-Shatti, M. A. (2007). Towards a framework for a personal learning environment: A blog. Available at: http: mohamedaminechatti.blogspot.com/2007/03/lms-vs-ple.html

Al-Shuhri, A. (2013). The effect of using integrated education on learning some grammars among English language students at King Khalid University and their attitudes towards it. Unpublished $\mathrm{PhD}$ thesis. Umm Al-Qura University, Saudi Arabia.

Al-Shuhri, M. A. (2014). The Effect of using Noor Educational Portal on Learning English Grammar among Second Grade Students in Riyadh City. Master Thesis. Faculty of Social Sciences, Department of Curriculum and Instruction, Imam Muhammad bin Saud Islamic University, Saudi Arabia.

Al-Saeagh, R. B. (2012). The Impact of using programmed learning based on animation in academic achievement in English language among sixth grade students and their attitude towards it. MA thesis. Faculty of Education, University of Umm Al-Qura, Makkah, Saudi Arabia.

Al-Sanea, O. J. (2009). Reasons for the low level of primary school pupils in the English language subject from the point of view of their Teachers in Kuwait. Journal of Reading and Knowledge, 91, 1441.

Al-Saghir, K. M. (2008). The Constraints of learning English in Saudi Arabia. Al Jazeera. Available at: www.al-jazirah.com/2007/20070303/en2.htm.

Al-Deferi, A. K. (2014). An e-learning environment-based program for the development of basic leadership skills among the Students of the Faculty of Education in Kuwait. Journal of Reading and Knowledge, 149, 33-59.

Abdel Hamid, A. T. (2010). E-Learning and Education Technology Innovations. Modern Library.

Abdel Hamid, M. (2009). Network Education System. Cairo: World of Books, II. 
Abdel Dayem, K. and Nassar, A. (2012). The use of e-learning environments and its relationship to Achievement motivation among Al-Quds Open University students in North Gaza Educational Zone. Palestinian Open Education journal, 3 (6), 171-216.

Abdul Latif, H. (2014). The Impact of Developing Virtual Learning Environments in Light of Their Design Standards on providing students with educational design skills for e-courses. Unpublished MA thesis. Ain Shams University, Faculty of Specific Education, Department of Educational Technology.

Al-Zoubi, R. R. (2013). Engaging students in learning English and its relation to each of the students' relationship with the English teachers and their attitudes towards learning it. Jordanian Journal of Educational Sciences, 9 (2), 221-241.

Aql, M. (2012). Designing an e-learning environment for developing the skills of designing learning items. Journal of Scientific Research in Education, 13(1), 387-417.

Arend, B. (2009). Encouraging critical thinking in online threaded discussions. The Journal of Educators Online, 6 (1), 1-23.

Belfer, K., Nesbit, J., Leacock, T. (2002). Learning object review instrument (LORI). Version 1N4.

Chou, S. W., \& Liu, C. H. (2005). Learning effectiveness in a web-based virtual learning environment: A learner control perspective. Journal of Computer Assisted Learning, 21(1), 65-76.

Conceicao Runlee \& Daley, B (2003). Constructivist Learning Theory to Web-Based Course Design. An Instructional Design Approach.

Fadel, H. (2016). The effect of blending e-learning environments and social media on developing the skills of teacher-students in the field of computer maintenance. Journal of the Faculty of Specific Education, 3.

Hamdy, R. M. (2011). The Impact of Employing a Personal E-Learning Environment in Developing Content Design Skills. The 7th Scientific Conference of the Arab association for Educational Technology (E-Learning and the Challenges of Arab: Interactive Learning Communities), Egypt, 1, 315-354.

Harrington, C. \& Aloni, M. (2013). Promoting critical thinking through online discussion: Developing questions and managing conversations. Paper presented at Lilly Conference on College and University Teaching, Middlesex County College.

Hassan, E. (2015). The reality of using virtual classrooms in the distance education program from the perspective of faculty members at King Abdulaziz University in Jeddah (MA thesis). Umm Al-Qura University, Kingdom of Saudi Arabia.

Hou, H. (2010). Explore the behavioral patterns in project-based learning with online discussion: quantitative content analyses and progressive sequential analysis. The Turkish Online Journal of Educational Technology, 9(3).

Ibraheem, A. \& Ismail, A. (2014). The Effect of Environment Design of Cooperative Electronic Learning Based on Some Websites Tools 2 According to the Principles of Communicative Theory on the Development of Personal Knowledge Management Skills for Computer Students. Journal of Arabic Studies in Psychology, 81-184.

Khamees, M. A. (2000). Standards for the design and production of multimedia / interactive systems. Seventh Scientific Conference of the Egyptian Association for Educational Technology. Under the title of educational technology system in schools and universities. Faculty of Specific Education, Kafr El-Sheikh: Tanta University. 
Konlechner, K. (2014). Virtual Learning Environments in IB schools-potential, possibilities, and pitfalls (MA. thesis). Swedish Research School of Management and Information Technology, Sweden.

Krauss, F., Ally, M. (2005). A Study of the Design and Evaluation of a Learning Object and Implications for Content Development. Interdisciplinary Journal of Knowledge and Learning Ob jects, 1(1).

Linn, M. C. (2000). Designing the knowledge integration Environment. International journal of Science Education, 22 (8).

Madi, A. (2015). Creating a social network-educational environment and its effectiveness in developing the skills of e-learning environments and sel-learning among educational technology students (MA thesis). Faculty of Education, Ain Shams University.

Mooney, A. \& Bergin, S. (2014). An analysis of alternative approaches for the distribution of lecture notes with the aid of a virtual learning environment to promote class engagement. The All Ireland Journal of Teaching and Learning in Higher Education, 6 (2), 1761-17613.

Marouf, S. and Nasser, Y. (2010). Students' attitudes toward English language in relation to achievement in the light of the prevailing classroom management patterns (field study on a sample of firstgrade secondary students in Damascus Public and Private Schools. Damascus University Journal, 26, $(1+2), 739-771$.

Al-Maghawry, T. (2015). Virtual University. E-Learning Journal, (9). Alexandria University.

El-Manaei, A. (2002). Educational Computer Software: Production and Evaluation Standards. Mission of Education - Sultanate of Oman, (2), 106-111.

Mansour, A. H. (2001). E-School in Learning Environments. The 8th Annual Conference of the Egyptian Association For Learning Technology in cooperation with the Girls College - Ain Shams University, 29-31 October, Cairo.

Moore, Joi L.; Dickson-Deane, Camille; Galyen, Krista. (2011). e-Learning, Online Learning, and Distance Learning Environments: Are They the Same? Internet and Higher Education, Journal Articles; Reports - Evaluative v14 n2,129-135 Mar.

Al-Najar, M. (2013). Strategies for Professional Web Development from Web 1.0 to Web 3.0. Academy For publishing and scientific services.

Oliver. K. (2000). Methods for Developing Constructivist Learning on the Web. Educational Technology, 40

Omale, N.j Hung, W., Luetkehans, L., Plagwitz J. (2009). Learning in 3-D multiuser virtual environments: Exploring the use of unique 3-Dattributes for online problem-based learning. British Journal of Educational Technology, 40.

Al-Wahr, M. (2002). The degree of science teachers' knowledge of structural theory and the impact of their academic and educational qualification and gender. Journal of the Educational Research Center, 22, Qatar University

Qatami, Y. (2000). Child Cognitive and Linguistic Development. Al-Ahlia for Publishing \& Distribution. Amman, Jordan, 4-83.

The Eighth Conference of the Egyptian Association for Educational Technology. (2001). In cooperation with the Faculty of Girls, Ain Shams University. 29- 30 October Cairo, 505 - 512.

The 10th Conference of the Egyptian Association for Educational Technology. (2005). In cooperation with the Faculty of Girls, Ain Shams University. Entitled "E-Learning Technology and Total Quality Requirements". 5-7 July. 
The $13^{\text {th }}$ Conference of Information Systems and Computer Technology. (2006). Egypt: Cairo. 14-16 February.

Romero-Frías, E., \& Arquero, J. L. (2013). A view on personal learning environments through approaches to learning. International Journal for Innovation and Quality in Learning, 1, 29-36.

Salman, A. R. (2010). The effect of using a smart virtual learning environment with variable cognitive controls on the development of Innovative thinking among educational technology learners. PhD thesis. Cairo University, Egypt.

Sayed, N. (2016). The effect of a proposed e-learning environment based on structuralism on the development of design skills and the production of digital repositories for the students of educational technology based on their cognitive needs (PhD thesis). Cairo University, Egypt.

Van Harmelen, M (2006): Personal Learning Environments. Proceedings of the 6th International Conference on Advanced Learning Technologies (ICALT 06), IEEE. Available at: http://octette.cs.man.ac.uk/jitt/index.php/Personal_Learning_Environment

Wu, P., Yu, S., \& Wang, D. (2018). Using a learner-topic model for mining learner interests in open learning environments. Journal of Educational Technology \& Society, 21(2), 192-204.

Yang, F., Tsai, M., Chiou, G., Lee, S., Chang, C., \& Chen, L. (2018). Instructional suggestions supporting science learning in digital environments based on a review of eye tracking studies. Journal of Educational Technology \& Society, 21(2), 28-45. 